\title{
Managing Work and Care: A Difficult Challenge for Immigrant Families
}

\author{
Karin Wall and José São José
}

\begin{abstract}
This paper explores the strategies used by immigrant families to reconcile work and care for young children in Finland, France, Italy and Portugal. Drawing upon interviews with couples or lone parents who have children below age ten, it shows that immigrant families rely on a diversity of work/care strategies. These strategies include extensive delegation of care (mostly to formal or non-familial informal care), negotiation of care within the nuclear family (both partners sharing the care responsibilities as well as older child care), mother-centredness (mothers cutting back on working hours), child negligence (leaving children alone) and the superimposition of care upon work (taking children to work). Almost all immigrant families, but especially first-generation ones, suffer from the absence of close kin networks to support childcare, strong pressure to work and from work (long or atypical hours) and various integration problems such as social isolation, lack of information on services, and problems with housing. However, our findings show that migration patterns, among other factors, have a significant impact on work/care strategies. Highly qualified "professional migration" is more associated with extensive paid delegation (often private and high-cost), "marriage migration" with mother-centredness, and "unskilled worker migration" with low-cost solutions supplemented by workplace care, older child care and negligence. First-generation unskilled worker migrant families are more exposed to occupational and residential segregation, atypical working hours, low earnings and difficulties in managing work and care for young children. Findings point to the still weak regulatory function of the different welfare states in the protection of these families.
\end{abstract}

\section{Keywords}

Immigrant families; Reconciliation of work and family life; Social care; Migration trajectories; Finland; France; Italy; Portugal

\section{Introduction}

One of the most significant changes in European societies since the Ig8os is the increase in and diversification of immigration. Contrary to expectations

Address for correspondence: Karin Wall, Institute of Social Sciences, Av. Professor Aníbal de Bettencourt 9, I6oo-I89 Lisbon, Portugal.Email: karin.wall@ics.ul.pt 
in the I970s, when the intense labour migration movement of the ig6os began to slow down and the recruitment of new immigrants became more restrictive, migrant inflows increased again during the rg8os and I99os, bringing into Western European countries not only unskilled workers to satisfy specific labour market needs, but also an increasing number of asylum-seekers, family-reunion migrants, highly qualified workers and illegal migrants (King I993; Castles and Miller 1998; Salt 2000).

Our main concern in this paper is with the work and family lives of immigrant families. By focusing on a very specific but crucial problem in family life- how to manage work and care responsibilities for young children - our aim is to identify the strategies adopted by immigrant families in order to organize work and family life. From a broader perspective, however, we can say that analysis of the work/life strategies of families will give us a privileged insight into the integration process of immigrant families in the receiving societies. If, as we know, immigrants face strong pressures arising from work (long working hours, atypical timetables), from economic difficulties, from racial and social discrimination and from contrasting cultural and religious values, then the reconciliation of work and family life is likely to be a sensitive point revealing the specific tensions and vulnerabilities of the position of immigrant families in the receiving societies. How do immigrant families deal with these patterns of "vulnerability" and to what extent do they hinder accessibility to the social care models of the host society?

To explore these issues, our analytical framework looks at the processes of social care and work/life balance as well as those related to migration. With regard to the first, our primary focus is on social care practices, broadly defined as the assistance and surveillance provided by paid or unpaid, professional or non-professional carers (within the public or the private sphere) in order to help children or adults in their daily lives and activities (Daly and Lewis 1998). These practices are embedded in work/life patterns whereby families develop specific strategies to manage work and care responsibilities (Drew et al. I998; Crompton I999; Dulk et al. I999; Garey I999). They may include cutting back on working hours, adapting parents' work schedules or delegating care to professional and informal carers. "Reconciliation" and "balancing" are the concepts currently used to analyse this process. These concepts seem to imply that some form of conciliation or equilibrium between the two spheres is always achieved, and this represents an analytical drawback. In fact, one of the important issues in this paper may be to question the idea that receiving societies always develop accessibility to a "reconciliation" model in which the state, the family and the private and voluntary sectors come together to provide adequate care. Reconciliation of work and care may not always be possible and this may lead to alternative arrangements such as taking children to work or leaving them to fend for themselves. Therefore, although we shall also sometimes use these concepts in our work, in general we prefer the rougher and more neutral concept of "managing" work and family life (Hantrais I990).

Work/family strategies in the receiving society must also be seen in the context of migration. Reasons for migration, social integration in the receiving society and ethnic characteristics may vary considerably and this will 
have an impact on work and family life. Analysis of families' migration trajectories and the nature and duration of their migration project allowed us to identify different migration patterns ${ }^{1}$ in our study of immigrant families. The main migration patterns we found are labour or worker migration (unskilled, long-term), student migration, highly qualified professional migration, asylum-seeker migration and "mixed-marriage" migration (where an immigrant woman migrates in order to marry a national from the host society). One of the key aims of our analysis will be to see if these different types of migration patterns are linked to certain types of work/care strategies.

In this paper we will draw upon the results of the SOCGARE Project which sought to understand the work/family balance of different kinds of constrained families in five countries (Finland, France, Italy, Portugal and the UK). ${ }^{2}$ One segment of the data of this project consisted of interviews with 72 immigrant families with young children (aged Io or less) and working parents (part-time or full-time) ${ }^{3}$ living in France, Finland, Portugal and Italy; it included couples with children as well as some lone parents. From the point of view of migration, however, the national samples within this larger sample of working parents with young children represent many different types of migration patterns as well as sending countries. This makes it difficult to build in a strictly comparative perspective across the national samples. But it allows us, nevertheless, to carry out an exploratory qualitative analysis which examines the specific constraints faced by immigrant families as well as the main linkages between some contextual variables, such as migration patterns, ethnicity, or social networks, and the work/care strategies of immigrant families. ${ }^{4}$

In order to deal with the diversity of the national samples we will begin by analysing the work/care strategies within each national sample. In the process we will seek to identify and explain, on the basis of a detailed description of some typical "cases", what relationships arise between certain types of immigrant families, patterns of vulnerability and specific strategies for managing work and care. Against this background of case-types, we will then try to understand and discuss some of the main factors involved in shaping work/care strategies.

\section{Immigrant Families in France}

The French sample of ig families ( 16 couples with children and three lone parents) was collected in Rennes and includes some diversity with regard to countries of origin, migration patterns and social position of immigrant families. All the immigrants are of African origin. Six couples are mixed Franco-African couples and the African partners come from Tunisia, Mali, Burkina Faso and Senegal. The other families come from three regions of Africa: the Maghreb, West Africa (Mauritania, Senegal, Burkina Faso, Mali) and Central Africa (The Republic of Congo and the Democratic Republic of Congo). Differentiation is strongest, however, from the point of view of the migratory pattern: some came seeking political asylum, many arrived as students, others came to marry a French husband; only one came as an unskilled labour migrant. Although all of them may be considered first-generation 
Managing work and care through mother-centredness:

Mother-centred care

IO

Managing work and care through extensive delegation:

Extensive formal care

Managing work and care through negotiation within the family:

Shared parental care

Shared familial care

Not managing work and care without child negligence:

Standard formal care and self-care

Extensive formal care and self-care

migrants, the social position of these couples differs quite strongly: some men, mostly French nationals in mixed-couple families, are qualified professionals or managers, others are clerical workers and some are employees in the service or industrial sectors. Finally, in relation to the family division of paid work, we have a mixed profile: the dual-earner/dual-carer model (both working full-time) appears alongside many cases of the male-breadwinner/ female part-time-carer model.

\section{Work/care strategies of immigrant families}

The most common work/care strategy of these families is what we called the "mother-centred" strategy, where mothers cut back on their working hours and organize their work around the children's nursery/school timetables (see table I). Many women in these families did not work at all when the children were below age 3 and now they have part-time jobs or training courses that enable them to be available for children after school and on Wednesdays when there is no school in France. Liliane, for example, works as a nursing auxiliary from 5 to 8 a.m. so that she can care for her I-year-old at home and be available for her other school children during the day (her husband is a plumber, and they are asylum-seekers from Zaire).

Many of these mothers are clearly what we might call voluntary stayat-home mothers or part-time workers. They portray mother-centredness as an option that addresses their identities as women and the care needs of children:

"It's the woman who raises her children, I think this is good for the child, the child needs a mummy more than a daddy... You, you are with your child... and it's better if you yourself look after your children." (Amok, Mali, no professional qualifications, low-income family) 
In some cases, however, the emphasis is on constraint rather than choice. The involuntary component is expressed through nostalgic recollections of rural African women who take their children to work, the desire to train in order to find well-paid full-time employment and many statements referring to the fact that they are looking for new jobs. Women who already had some qualifications or held down a reasonably good job in the sending country are more likely to have constrained mother-centred strategies:
"And now, since October, I've started on a course. I'm training to be a nursing helper... Because my basic training is as a shorthand typist. But with that, it's impossible to find work here. So first I improved my schooling level. Then in I999 I was pregnant... And then in 200I I decided to become an assistant nurse. And now, at the end of March, I will start looking for a job." (Dielika, from Mali, worked irregularly as a waitress before pregnancy, child 2 years old and in a crèche since $\mathrm{D}$. started her training)

Managing work and care through negotiation within the family or extensive delegation are two other possible strategies. In the former strategy, work/ care balance is achieved through the negotiated, mutual adjustment of couples' (or of family members') working hours and care responsibilities. It may take shape in different types of care arrangements. "Shared parental care" is an arrangement that relies on the sequencing of care provided by both members of the couple whereas "shared familial care" involves several members of the family. Ursule and her husband (from Congo, both former students in France) are a good example of this strategy. They have three children of their own (aged 8 years, 3 years and 9 months) and a stepdaughter aged I5 $_{5}$. Ursule works as a night nurse and her husband, a teacher, has a daytime schedule and is at home in the evening and at night; the stepdaughter is essential to care for the children in the early morning after father has left home and before mother arrives at 7.30 a.m. This reliance on an older child is considered by the interviewees as a common strategy in African families. Some of them looked after young children when they themselves were adolescents and frequent references are made to help provided by other women living in the same household.

The second strategy (extensive delegation) implies handing over care responsibilities for children to carers who look after them for long periods of time. Delegation based on informal carers (grandmother, childminder or a living-in family member) is usually low-cost and offers flexible and regular support, while delegation based on formal care services has to rely on services with very long opening hours (afternoon and homework clubs, school day care, holiday centres and so forth, usually requiring some payment). This is how Lydie and her husband, both working full-time (8 a.m. to 5 p.m.) balance work and care for three children aged 6 years, 3 years and I4 months. The children are in formal care institutions from 7.30 a.m. to $5.30 / 6$ p.m. every day of the week, including Wednesdays. The couple lives in a low-rent apartment, they are not very well off and often send money to their families in Congo. Lydie arrived in 1994, to join her husband who came as a postgraduate student, but she was only able to apply for training 
and a job in 1997 after getting her residence permit. She stayed at home for six months when her last son was born and then put him in a day-care centre.

The last option — not managing work and care without child negligencerelates to situations where children are left alone at home (self-care) or are looked after by other young children (aged io or less). ${ }^{5}$ In the French immigrant families, this strategy occurs in two lone-parent families with low incomes, long working hours and no family support. Julia is a lone parent who arrived in France as an asylum seeker and has a child aged 6. She is in training during the day and works an evening shift in cleaning services from 6 to 8.30 p.m. Her little girl is in formal care until 5.30 , then comes home on her own (she has a key) and waits for her mother. Julia mentions neighbours who sometimes keep an eye on her daughter but she also says that the child usually stays on her own. Said, on the other hand, is an unskilled labour migrant and now works in a warehouse handling stores. He is divorced, his partner lives far away and his income ( $\left.€_{56} 6_{5}\right)$ is limited, notwithstanding a heavy work timetable starting at 7 a.m. This makes it impossible for him to be there for his 9-year-old son in the morning before he goes to school, in the afternoon at 4.30 or on Wednesdays (the activity centre is considered to be too expensive). Said rings to see if everything is all right. In summary, Said's problems in managing work and care seem to be closely linked not only to his situation as a labour migrant but also to his position as a lone parent. Difficulties are related, on the one hand, to the type of job (manual, low-paid, with long and atypical working hours) and, on the other hand, to isolation as a lone parent who receives no support from his expartner or other relatives.

Going beyond this description of work/care strategies implies looking at variables such as immigration history or family trajectories which might shape and explain certain types of work/care strategies. In the case of the immigrant families in Rennes, we were able to identify three distinctive patterns of migration which are strongly linked to specific ways of managing work and care for young children.

\section{Migration patterns of immigrant families}

In the mixed marriage migration pattern a foreign wife comes to live and build a family in France, her husband's country of origin. Usually the couple meets in Africa, either marries there and returns together or then gets married in France after some to-ing and fro-ing between the two countries. In this migration pattern, immigration and marriage weave into each other and may be regarded as the two interlocking features that shape family life and social care. The African women who immigrated to marry a French national are family-orientated (this was the reason for migration), give high priority to caring for young children and adopt a work/care strategy which stresses the role of the mother as the main carer. This strategy is influenced not only by family values but also by the immigrant mother's marginal position inside marriage and in relation to the labour market of the receiving country: the husband has his job, is the main breadwinner and is socially integrated, 
whereas the wife's integration derives from the husband's status, creating an initial sense of belonging to the host society but also of personal loneliness and social isolation ("having no outside" as one immigrant woman put it).

Motherhood intervenes fairly early on and typically leads to a mothercentred strategy due to the wife's weak or non-existent breadwinner role. These women are more protected from economic difficulties, from the total absence of kin networks (which exist on the husband's side) and the downward mobility of many refugee couples but they are constrained to a certain gender role inside the family which reinforces a traditional gender socialization. However, as the children get older, many of the women seek to alter their position and adopt new ways of combining employment and mothering. From this point of view, they are eager to take up the opportunities (for training, employment, care provision) which the receiving society, France in this case, offers them.

Migration patterns in which one or both members of the couples immigrated as students shape different work/care strategies. In couples where both have studied in France, the members of the couple are not only fairly well integrated culturally and socially but also have more similar positions/ qualifications with regard to the labour market and the breadwinner role. The meanings and forms of work/care management thus shift toward strategies that are much closer to common childcare arrangements of the receiving society: taking turns to be more available for care (negotiation), both working full-time and devolving care to many types of formal institutions (extensive delegation), buying in childminders to fill in the gaps. In some situations these are combined with a solution used by working women in the sending societies - a family member, such as a sister or a cousin - who lives in the household and lends a hand in care and household tasks.

Asylum-seeker families, as unskilled labour migrants, seem to have more problems in organizing work and care. It is important to underline two main features related to this pattern of migration. First, migration in these families happens nearly always at a later stage in the family life course. Unlike the students, who are usually single or in the first years of married life, these couples are forced to emigrate when they already have several children and are not so young. Family life as well as professional life may be brutally interrupted or sacrificed: as a result, part of the family, namely some of the children, are often left behind and stable jobs and careers are suddenly abandoned. Moreover, work/care strategies, which often relied on extensive kin support as well as domestic help, must be restructured.

Secondly, during the first years after immigration, there are strong economic constraints due to long periods of waiting for legalization, followed by entry into low-paid, unqualified jobs. Those who had previous qualifications may have to struggle to train and work at the same time, a problem that puts extra strain on the amount of time available for care. If they are lone parents (see Julia, above) they may have to juggle training, work and care at the same time. Legalization, housing, work and training to get a better job - in other words the elementary steps toward establishing a "normal" life in a new society - will be family priorities. In such a situation, care arrangements have to adapt to these priorities rather than the other way round and children 
may have to contribute to this effort by looking after their younger brothers and sisters, remaining in the sending country or staying alone with no one to care for them.

The first years after emigration are obviously the most difficult for refugee families. Families who have been in France for more than ten years may still complain of the difference in living conditions before and after migration. But they have gradually become integrated in the labour market and have a more stable economic and work/care situation.

\section{Immigrant Families in Finland}

The Finnish sample of immigrant families with young children was collected in the regions of Tampere and Helsinki and it included two main countries of origin: China and Estonia. In this paper, however, we shall only look at the Chinese families. All the immigrants in these ro families are firstgeneration migrants and there are only families of couples with children. Most of them are skilled-worker families who migrated in order to train $(\mathrm{PhD})$ and/or in response to employment/career opportunities in the skilled sectors of the labour market (highly qualified professional migration). Only a few came as unskilled immigrant workers.

\section{Work/care strategies and migration patterns of Chinese immigrant families}

The work/care strategies of the Chinese families are strongly centred on the dual-earner model, with both partners working full-time and extensive delegation of childcare based on inexpensive formal services which care for children all day (see table 2). Curiously, the one and only case of mothercentred care is related, as in many of the immigrant families in Rennes, to mixed-marriage migration. The other work/care strategies are linked to two main types of migration: short-term highly qualified professional migration and labour migration.

Table 2

Work/care strategies of Chinese immigrant families (Finland)

Work/care strategy

Number of cases

$\begin{array}{lr}\text { Managing work and care through mother-centredness: } & \text { I } \\ \text { Mother-centred care } & 7 \\ \text { Managing work and care through extensive delegation: } & \text { I } \\ \text { Extensive formal care } & \\ \text { Childminder } & \text { I } \\ \text { Not managing work and care without child negligence: } & \text { IO } \\ \text { Formal care (school, no extras) and self-care } & \\ \text { Total } & \end{array}$ 
Short-term professional migration involves families with high educational qualifications (both members of the couple, often engineers or physicists, strongly committed to their careers) who came to Finland to work or to work and study for a few years. These families do not usually have many problems with residence permits, income and housing, but their social and cultural integration in Finnish society is limited and not considered as a priority. English is the language they need for postgraduate studies and for work, Finnish is hardly spoken and most of their friends are Chinese and live nearby, especially if the family lives in the student-housing area by the university. In this context, care is organized around the resources which are most at hand and guarantee the children's international integration: Englishlanguage day-care centre and school (which have fairly long opening hours, from 8 a.m. to 5.30 p.m., and may cost up to E29o per month), fetching and taking by the father or the mother and some occasional support from other Chinese families if work finishes later than usual. Knowledge of other care arrangements and local services is limited and interviewees emphasize that they have little information at their disposal (for example, on babysitters and on childminders, a solution which some of them would prefer for children below age 3 ).

However, when families have been in Finland for a slightly longer period, this profile may undergo a few changes. Lin (a software engineer) and Ching (a research fellow) have been in Finland since I99I when they came to do their PhDs. They live in a rented apartment in a block of flats, speak a little Finnish and have decided to send their son, now aged 7, to a Finnish school. They hesitated about this decision for two reasons. First, although they feel they have settled in Finland, they are still thinking about going back to China, where English would be more useful; second, they are worried because of the Finnish school timetable (ending at I p.m.) as they feel their son is too young to stay alone in the afternoon; they have applied for an afternoon club (Ei36 per month) and are waiting for an answer.

A second profile seems to be more closely associated with unskilled labour migration. Only three worker migrant families were interviewed in Finland and the trajectories of the immigrant women are rather different. Two interviewees emigrated as single persons and the other came to join her husband who had found work as a cook in Finland (they set up a restaurant of their own some time later). Nevertheless, the families seem to portray some common vulnerabilities that contrast sharply with the highly qualified families already described.

Chinese worker migrants with work permits seem to have immigrated quite easily in the late Ig8os and early I9gos when there were labour shortages in Finland. As in other Chinese communities all over the world, many came to work in Chinese restaurants or families and then moved on to other jobs or tried to set up on their own. Having a restaurant, a café or a shop of your own implies long and atypical working hours. On the other hand, being a Chinese unqualified employed worker is not easy either, as it usually means working in catering or cleaning services and earning low salaries. These, then, are the main constraints faced by these families: long working hours in unqualified jobs or in self-employment, low income and fear of 
losing the job when working for others (one interviewee talked at length about how, in a previous job, she felt that she couldn't miss work even if the children were ill for fear of being fired). The work ethic is thus very strong and family life must adapt to work life rather than the opposite. As a result, the work/care strategies in these families are strongly connected to the care norm of "managing on your own". This means that care responsibilities must be managed as far as possible inside the nuclear family even if this implies getting young children to stay at home on their own or to look after other children, or taking children to work, if necessary.

Hua is a typical example. She arrived in Finland in Ig89 with a permit to work as a waitress in a Chinese restaurant. During that first year Hua lived in lodgings provided by her employer and worked 6o hours a week; she had no idea it was illegal to work so many hours. Hua married a Finn, has two children aged io and 4 and now works in the kitchen of a local elementary school. Her husband has a shop that is not doing well; he also has a drinking problem and Hua has already considered a separation. Family income is low $(€ \mathrm{I}, 796)$. In terms of care, one child is at school and the other in day care (€79 per month). The elder child, a girl, goes to school until I or 2 p.m., then stays alone at home in the afternoon; very often she also goes to fetch her brother from day care and gives him tea (formal care + self-care; see table 2).

At present, Hua is pleased with her job. As she works for the local authorities, she knows she has her rights and feels secure. Although she feels it is difficult to miss work as there are only three people in the school kitchen, she has no fear of being fired and is happy to be allowed to take the children to work when there is no school or if they are recovering from an illness:

"I have often taken the children along with me to work. They are bigger now, but they are often ill. Around a year ago I think it was about twice a month, sometimes a week, that I took a child along with me to work." (Hua, a kitchen worker with low income, over ten years in Finland, married to a Finn, two children aged Io and 4)

Contrary to the qualified Chinese immigrant families, these worker families are permanently settled in the host country and seek integration: they manage quite well in Finnish, they have more contact with Finnish people in their daily lives and the children go to Finnish day care and schools. However, long working hours, low salaries and strong pressure not to lose jobs seem to shape work/care strategies where children, rather than the parents and their jobs, are the adaptive element in work/life patterns. This sometimes leads to child negligence, but not necessarily.

Hua does not have reliable help from her husband. However, Wan, another Chinese mother who runs her own coffee shop where she bakes bread at dawn and cooks both Finnish and Chinese food, relies on her husband (who has normal working hours) to take and fetch their young child from full-time day care ( $€$ I6g per month). Care gaps are more likely to arise when children begin school and have short or interrupted school hours. Lack of informal kinship networks to fill in these gaps, more difficult access to afternoon clubs (compared to day care for children below age 7) and some 
social acceptance, in the host country, of leaving primary school-aged children alone in the afternoon, are the factors which appear to contribute most to the emergence of self-care, that is, leaving children alone without care.

\section{Immigrant Families in Portugal}

Portugal, along with Spain, Italy, Ireland and Finland, falls into a group of European countries that has registered a strong increase in immigration since the I980s. Unskilled worker migration from the African colonies, mainly from the Cape Verde islands, began in the ig6os to compensate for labour shortages caused by emigration (mainly to France and Germany) and the colonial war. However, it was in the late I970s and in the I980s and the I990s, after the Revolution (I974) and decolonization, that immigration from the former African colonies (Angola, Mozambique, Cape Verde, Guinea-Bissau, São Tomé) intensified (Pires I999). Today African immigrants account for almost half the foreign population in Portugal and the majority of them are from the Cape Verde islands.

The Portuguese sample of families was collected in the city of Lisbon, where most African immigrants are concentrated, and includes 2I Cape Verdean families (fourteen couples with young children and seven lone parents). Most of the interviews were carried out in socially deprived areasin new suburbs of social rehousing as well as in an older "slum" area where brick houses have replaced former wooden shacks. A few interviews took place in other suburbs of the city where some families have rented or are buying flats. The sample is therefore homogeneous in terms of the sending country but includes some internal diversity from the point of view of family forms, duration of stay and integration in the receiving society.

\section{General characteristics of Cape Verdean immigrant families}

Looking at the general characteristics of these immigrant families and their life histories, three striking features may be emphasized. First, the intensity of the migration phenomenon in the sending country. The life histories of the immigrant interviewees all tell us about the continuous circulation of men, women, young people and children. In the second half of the last century, destinations became more varied: the Cape Verdeans emigrated not only to Portugal and to other Portuguese African colonies but also to the United States, to Holland, Italy and Spain.

A second feature is related to the organization of family life, which contrasts sharply with what we might call the "European" family. Shaped by the historical and social contexts of slavery, African roots, migration and the struggle for survival, family life is more centred on the mother-child unit, on cohabitation and lone parenthood rather than marriage, and on considerable independence and sexual freedom of both women and men. Fertility, motherhood and fatherhood (rather than parenthood), and intergenerational support are basic family values but they are channelled through bonds and types of households which slip away from the nuclear family of couples with or without children. As a result, family transitions follow specific and diverse 
patterns that revolve around lone parenthood. Having children and independent motherhood are strongly valued, even by second-generation young women who are now less in favour of having many children. As one single mother put it:

"It's like this, we are not like the Portuguese. We, the mothers have their children, right?' By norm it's the mother who has the child and who takes care of the child. Of course, this means that I am alone in responsibility, anything that happens." (Daniela, 24, born in Portugal, secondary education incomplete, two children aged 4 and 2 from the same partner, cohabited for one year between the two births)

As a result, the small sample of immigrant families collected in Lisbon contains family forms and trajectories which are quite varied and also experienced as ethnically different: many are lone parents (seven) and among the families of couples with children, there are more cohabiting (eight) than married couples, and several are blended families with children from different fathers or partnerships.

Integration in the labour market is the third aspect that must be highlighted. Cape Verdean immigrants have traditionally worked in two main sectors: the building and public works sector (the men) and the cleaning and catering services sector (the women). Both have long working hours, with the building sector starting very early in the morning, often working overtime and at weekends, and on sites outside Lisbon which imply staying away from home for weeks or months. The cleaning sector, on the other hand, also has long or atypical working hours and, compared to the male wage in the building sector, very low salaries (rarely going beyond the national minimum wage).

It is important to underline the fact that African women are often confined to a certain sector of the labour market, to firms that clean offices and public buildings at dawn and in the evenings. These women have greater difficulty in obtaining the better-paid jobs in private homes or jobs as waitresses or shop attendants (taken up by Portuguese women or white, Brazilian or Eastern European immigrants). In the Portuguese sample, all the women except one are working full-time, nearly all in cleaning or catering services. Only one mother, eight months pregnant and with another child aged 2, has temporarily reduced her working schedule to part-time work (cleaning services in the morning, child in the care of a childminder).

These are some general features of Cape Verdean immigrant families that had to be mentioned. Cape Verdean immigrants are also strongly contrasted with the local population groups from a racial point of view but they are less so in terms of religion or language. If we look more closely at the sample, however, it is also important to emphasize some internal differentiation from the point of view of the migration trajectory. Some interviewees are firstgeneration migrants and others are what we may call second-generation migrants: they came as young children with one or both parents and a few were born in the host country.

This does not always mean that the social integration of second-generation families is very different. However, it sometimes implies a slightly higher 
educational level, a stronger family support network and having no plans to return to Cape Verde. In a few cases it also means acquiring some professional training and getting jobs with normal hours, outside the building/ cleaning sectors. Also, although the majority of families are worker migrant families, the sample has two cases of student migration and one case of what we might call employee migration (migration to Portugal, before decolonization, of an administrative employee, now a civil servant in a bank). Taking into account these differences, we were able to identify three main patterns of migration which influence families' strategies for managing work and care for young children.

\section{Work/care strategies of first-generation unskilled worker immigrant families}

First-generation unskilled worker migration is related to a long-term migration project which emphasizes access to paid employment, to food and better living conditions and, savings permitting, the building of a new house in Cape Verde to which to return after retirement. Some immigrants arrived in the late Ig6os, at the time of "the great famine" in Cape Verde, others in the ig8os or ig9os. Networks usually helped to find work and/or temporary accommodation inside the slum. Usually the man came first and the woman and the children came later; but some years usually went by before enough money was saved to pay for the travel expenses of those left in the sending country.

José and Domingas (aged $5^{\circ}$ and 44, cohabiting couple, both illiterate) are a typical example of immigration in the late ig7os. In Cape Verde, Domingas worked seasonally as a farm labourer, picking coconuts and cocoa, and later as a maid looking after small children. She started working when she was eight and never learnt to read and write. She went to live with José and his family when she was $\mathrm{I}_{5}$ and had her first child (one of five) aged I7 in Cape Verde. José emigrated soon after, was lodged by a relative in the slum, and started working in the building sector. A few years later, after "nailing together" a shack, he sent for his partner and child and, later, for his mother and brother. The wooden shack was gradually transformed into a brick house by José, but the family is still waiting for social rehousing.

First-generation immigration in the Iggos is not very different from this model. António, a bricklayer (earning $€ 65^{\circ}$ ) had already been working in Portugal for a few years when he met Dulce in Cape Verde during his holidays. Like Domingas, Dulce (now aged 37, one year of schooling, cohabiting) also stayed in the sending country for a few years, had her first two children there and then joined her man. She arrived in I994 but left the two children with her mother in Cape Verde, so that she could work harder. António had left the slum area by then and rented a small council flat nearby, with one bedroom (and some dampness). This is where they still live today, with four children, including the two elder children, who came in I998, and the other two born in Lisbon. This means that the four children (now aged I3, 7, 3 and 2) share the bedroom. Dulce first got a job through Cape Verdean friends cleaning in a factory. As it was very hard work she moved to a cleaning services firm where she now works in two shifts (from 7 a.m. to 
Work/care strategies of Cape Verdean immigrant families (Portugal)

I p.m. and from 6 to 9 p.m., earning $€_{350}$ ). It is difficult to manage work and care, but Dulce has always relied on her older son to look after the other children in the morning; at 8 a.m. he takes them to school and day care (private non-profit, $€ 69$ for two children). During the day, this son is quite independent: for example, for several years now, he has been going home at lunchtime to cook his lunch. Dulce fetches the other children in the afternoon but then leaves them alone for a few hours as she leaves for work at 5 p.m. and her older son has school until 6.30 p.m. (formal care + older child care + child negligence; see table 3). Dulce and António would like to go back to Cape Verde one day and they have already started building a house there.

The work/care strategies in this family highlight the main problems faced by first-generation migrants with young children. Incomes are low, housing conditions are bad, working hours are long and atypical, and formal care services, even though they are fairly cheap, do not cover the varied and long care needs of children. Low-cost extensive delegation, older child care and child negligence are therefore the main strategies used. If there is a grandmother who joined the family (an exceptional situation for first-generation migrants, only one case), then informal extensive delegation is a solution. However, in the absence of this solution, the gaps in care (early in the morning; when primary school ends; late afternoon; working overtime at weekends) will be managed with the means at hand: primary school children look after babies and learn how to cook, young adolescents look after several children, children stay on their own. In some families, such as Dulce's family, the parents manage to cover almost all the care needs with the help of an older child.

Even when the children are all younger, it is still the oldest child who, early on, will begin to take on childcare responsibilities. For example, Anita, Maria's 7-year-old daughter, has school and after-school club during the day, 
but in the morning, between 6.30 and 8.30 , she takes care of her 3 -year-old sister, gives her breakfast and dresses her (formal extensive care + child negligence; see table 3). Maria works a cleaning shift from 5.30 to $8 \mathrm{a} . \mathrm{m}$. and her partner works in the building sector and leaves for work at 6.30 a.m. Before Anita started going to school, the family used to pay a babysitter to be there in the morning and then take the two children to day care (€75 per month, when day care already cost $€_{55}$ per child). As this was very expensive, they decided to "try" leaving Anita on her own with her sister in the early morning and on Saturday mornings when the parents work overtime. Anita does not like staying alone; she can't sleep when the parents have left so she turns on the TV. Maria and her husband have brothers and sisters living in Lisbon but they all work long hours, so time to help care for children is not available. As another interviewee put it:

\begin{abstract}
"No one is available here, everyone has to work. . . So the Cape Verdeans, we cannot reconcile the education of young children with two homelands. Not me personally, I have managed, but I am a drop of water in the ocean. But the Cape Verdean immigrant loses her child at the age of ten and many lose them many years before. They really lose them. The children are used to being alone, they run around, they finish school and get home hours later, they don't do their homework." (Guida, school helper with normal working hours, 39, secondary educational level, arrived in Portugal aged 8 in I97I)
\end{abstract}

\title{
Work/care strategies of lone-mother immigrant families
}

When the first-generation migrant is a single mother, the pattern of social exclusion becomes more pronounced. Rosário, aged 26, is an example of this. Rosário was a 3-year-old child when she was left with an aunt in Cape Verde. Her parents separated and both emigrated abroad and remarried; since then, she has only seen her mother once, when she was aged I3. In Cape Verde Rosário completed four years of primary schooling and then worked irregularly as a daily in restaurants and in private houses. She had her first child at the age of 20 but never lived with the father of her child. It was against this background that Rosário decided to emigrate in 1995, hoping to improve her life and earn more money. She came on her own, leaving her I-year-old daughter with her aunt, and with no relatives in Portugal who might help her. However, she had contacts to find work and went to be a maid in a private house in return for lodgings and food. After six months she went to work in another private home, but this time for a salary.

Some time later she met a new partner, and had a second child. The couple lived with his parents first and then got a small rented flat of their own. However, after two years they separated and Rosário could not afford to go on paying for the flat. She was taken in for three months by a friend from work (also a lone parent) and then rented a room in another immigrant's house in the slum area. Rosário is so ashamed of her room in the slum that she has not told her work colleagues where she lives. Currently she works in a cleaning services company from 8 a.m. to 5 p.m. and earns $\epsilon_{35}$. 
With this salary and a small amount of family benefit, she has to pay her rent (€ioo), a local childminder for her daughter ( $\Theta_{1}$ Ioo), bus tickets, food and clothes, and try to send some money to her daughter in Cape Verde. Most of the time she cannot make ends meet and runs out of money for food. She does not receive any assistance from her former partner and she has not seen her older daughter, now aged 7, for six years. Another of her worries is the fact that the childminder is unreliable and sometimes leaves the small children alone with an 8-year-old daughter. Rosário feels that she has been living in hell since her separation.

\section{Work/care strategies of second-generation worker immigrant families}

Second-generation worker families and those who came as very young children were often brought up in the type of care situations that we have just described. They lived in shacks, income was low, care responsibilities and household tasks were distributed between the parents and the older children, and pressure to start working, in order to boost family income, was strong. Their individual and family/work trajectories, nevertheless, are not always the same. Some never finished compulsory schooling (that was six years until the late I980s, nine years since then), started working when they were I2 or I3 and had children very early on. A few started working but managed to work and go to school at the same time, others went back to school and occupational training later on.

Family support is another important factor in the work/life strategies of these second-generation families. Lone parents, and some couples with children, will often have support from close family members (parents or just a mother, brothers and sisters). Adolescent single mothers, if they do not leave home to cohabit with their partner, will stay on in an extended family household, where brothers and sisters and a grandmother will be available to help care for young children. This does not mean that child negligence does not occur (one case, a primary school child who does not have an after-school club at the school in the new suburb where the family lives). But work/care strategies in second-generation families are more systematically associated with grandparental support and with paid extensive delegation that covers the needs for childcare, mainly due to parents' more social working hours. If we look at the work/care strategies of some second-generation families, we find the following typical situations.

(a) Grandparental care. Albina was born in Portugal (her father arrived in the late ig6os, her mother some years later) and only has 4 years' primary school education. She is 25 years old, lives with her partner who is 32 , and has two daughters, one aged 5 and the other II (born when Albina was I4 and still living at home). Like their parents before them, Albina works in the cleaning sector (she's a daily, from 8 a.m. to 2 p.m., Monday to Friday) and her husband works in the building sector (Monday to Saturday). Her mother cares for the youngest child during the day and gives support in other situations, as she is retired and living in the same building. The older daughter goes to school on her own but has lunch with grandmother 
(who also "keeps an eye on her" after school). The family used to live in the slum area but was moved to two low-rent flats in a social rehousing quarter.

Another typical situation of grandparental care is linked to cases of single adolescent lone mothers who go on living at home. Francisca (i8 years old) is the daughter of a separated lone mother with four children and is herself a single lone mother with a baby of 5 months. She found schoolwork difficult, failed repeatedly and only completed the sixth grade. She began cleaning as a young adolescent and has had a work contract in cleaning services for two years now, earning $€_{350}$ (I6 is now the legal age for working). She works from 9 a.m. to 5 p.m. during the week and from 9 a.m. to I p.m. on Saturdays. Her mother (at home, with health problems) cares for the baby and another grandson (2 years old) - the son of Francisca's sister (23) who is also a single mother living at home and working in the same firm as her sister. Francisca rarely sees her former boyfriend and she is disappointed that he never comes to see their baby. Francisca has a dream: she would like to emigrate to Luxembourg.

(b) Extensive formal care. Dalila's parents arrived in the I960s, at the time of the great famine in Cape Verde. Dalila is 25 and works as a media library coordinator in an activity centre for young people (9 a.m. to 5 p.m., earning E6oo). She started working in cleaning services when she was 13 to help her parents ( 5 children). However, as she was a good student, she decided to go to school in the evening and managed to complete secondary school. She had a first partnership that only lasted a few months but has lived for six years with her present partner (aged 40, metal-worker, a first-generation migrant who has four other children in Cape Verde). The couple lives with the eldest stepdaughter, aged I9, who arrived a short time ago to work in Portugal. Dalila's 2-year-old son is in day care (private non-profit, open from 8.30 a.m. to 6.30 p.m., $E_{52}$ per month) and it is Dalila who takes him and fetches him. Her parents live near her workplace and cared for the child until he was a year old; however, as her mother has health problems, Dalila decided to put the child in day care fairly early on.

(c) Paid childminder (with some negotiation inside the family). Jamila (25) and Dajaré (23) are a cohabiting couple with a six-month-old baby. They both arrived in Portugal as young children. Jamila was the eldest of four boys so he left school at I 3 and started working; a year later he went back to school at night and while working still managed to finish basic schooling (nine years). He was employed in the army for four years and then trained as an "activities coordinator"; at present he is under instruction on another training course on educational intervention (9 a.m. to 5 p.m.) and will start working again in a few months. Dajaré (secondary school complete) has a more complicated timetable with two alternating shifts (Io a.m. to 7 p.m. for two days, from 5 p.m. till midnight next two days, weekends included) in a McDonald's food chain restaurant; she has quite a responsible position and earns $€_{575}$. Both Jamila and Dajaré have parents who could look after the baby but they live far away. Their son is cared for by a childminder during the week (€i2o) 
and by Jamila in the evening and at weekends when Dajaré is working. He had no sisters so as a child he learnt how to do household work and care for his younger brothers.

\section{Work/care strategies of student immigrant families}

A last profile is associated with student migration (as well as a case of "employee migration" where the immigrant family managed to send the second generation to university). The work/family life of these migrants contrasts sharply with the patterns of vulnerability we have examined so far. Independent motherhood is still strongly emphasized but the difficulties of atypical working hours and very low salaries no longer influence the work/ care strategies. Dores is a good example. She came to Portugal with a scholarship to go to university. She got pregnant two years later, had her child as a single mother, started working part-time giving private lessons and managed to finish her degree. She had a second child from another partner II years later. At the time of the interview she was living with her two children

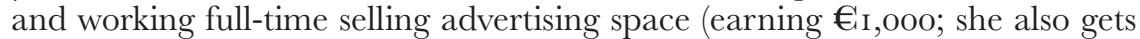
maintenance from the father of her eldest child, a medical student she met at university). The youngest child goes to a private not-for-profit primary school (9 a.m. to 7 p.m., E195); he is taken by his mother in the morning and usually fetched by his sister in the evening (extensive varied care; see table 3 ). Dores has no close family members to give her support and experiences some social isolation.

In summary, Cape Verdean immigrant families portray specific patterns of vulnerability which influence work/care strategies. Unskilled worker migration, associated in this case with strong ethnic contrasts (racial and familial) and social exclusion (segregation in terms of housing and the labour market), shapes work/life patterns in which parents work full-time with difficult schedules and low salaries. Extensive delegation, both formal (low-cost, private non-profit) and informal, is the main care solution but it does not always cover all the care needs; in other cases, its cost is too high and leads to situations of extreme poverty. To deal with care gaps, families rely on older child care when this is possible but they also ask young children below age Io to stay alone or to look after a younger child. These strategies reproduce work/life patterns from previous, rural or migratory, contexts or experiences and as such they are recognized as "normal" solutions, which does not mean that families do not feel constrained and concerned.

Families also complain about social isolation, especially first-generation ones. Family support for childcare rarely exists in first-generation families and, while immigrant networks are important for finding work or lending an occasional helping hand (with house repairs, for example), time for regular care is a rare resource in all families and social networks cannot deal with this need. Finally, family life, more centred in Cape Verdean families on lone motherhood, is another factor that intensifies the pattern of vulnerability. Women in unskilled jobs tend to earn less than men do but they often have atypical working hours or shift work. Unskilled first-generation lone-mother families thus emerge as the most vulnerable type of immigrant family: they 
are not entitled to any special benefit, ${ }^{6}$ they rarely receive maintenance from the fathers, ${ }^{7}$ family networks are absent and they work in low-paid jobs with long working hours.

\section{Immigrant Families in Italy}

\section{General characteristics of Moroccan immigrant families}

The sample of 22 Moroccan families with young children was collected in three different regions of Italy: Veneto, Emilia-Romagna and Tuscany. Like the Cape Verdean immigrants, they came to the host country looking for work and better living conditions (labour migration) and their jobs are generally low-skilled and low-paid in the industrial and service sectors. Nevertheless, there are some important differences. First, Moroccan immigration is more recent, with most interviewees arriving in the late I980s and during the I9gos (first-generation ${ }^{8}$ ). Moroccan immigrants, both women and men, also have higher educational qualifications than the Cape Verdeans and more geographical mobility. Many migrated to other European countries before coming to Italy while others moved from one region of Italy to another in search of better work and living conditions. Although this does not alter the basic characteristics of integration in the host society (such as housing problems, illegal status during the first years of migration, jobs with long or atypical working hours), it makes for a more varied integration in the labour market: some self-employment, factory work (sometimes skilled) as well as jobs in the catering and cleaning services, the latter both in private houses and institutions. It also leads to less residential segregation. Some families live in small urban "ghettos" but others are dispersed and living in different urban or rural areas where they may receive quite a lot of support from local services and Italian families.

Another important difference is related to the family dynamics of Moroccan migrants. In contrast to the Cape Verdean families, family life is organized around marriage and the married couple with children (20 families in the sample and only 2 divorced/separated mothers), and there are no cohabiting couples or single lone mothers. ${ }^{9}$ On the other hand, religious and family norms underline women's domestic roles, their dependence on the male breadwinner, and the religious precept that a woman "should be at home". Cultural pressure for stay-at-home mothers is therefore quite strong, and this is reflected in different ways in the interviews: there are references to husbands who do not or did not allow their wives to work, there are words that underline the mother's unique care and educational roles, and there are male interviewees who refer to their wives as "housewives" even when they work part-time. However, counter-pressures are also strong: the wife's participation in the labour market is regarded as essential for family income and the migration project, and the example of working women, not only in the host society but also in urban Morocco, is often referred to as a positive tendency. Overall, then, we can say that the attitudes to gender roles are undergoing important changes and often emphasize a more flexible interpretation of traditional norms. As one interviewee put it: 
"It's difficult to follow the rules of religion, for example that I should never leave my house... Everybody has to work, we need a lot of money to live on." (Nadia, $3^{8}$, secondary schooling, domestic employee working full-time, five years in receiving country, practising Muslim)

In short, the Moroccan families with young children feature some significant cultural contrasts (religious, linguistic) in relation to the population of the host society but they seem to be slightly more integrated socially than the Cape Verdean immigrant families: segregation in the housing and labour markets is less pronounced, racial contrasts are less strong, higher educational qualifications do not give access to qualified jobs but they facilitate language acquisition, helping children with schoolwork and dealing with institutions in the host society. Finally, family life centred on marriage and the couple makes it easier to avoid the severe forms of vulnerability associated with lone motherhood in the Cape Verdean families.

\section{Work/care strategies of Moroccan immigrant families}

If we now examine the work/life balance of the Moroccan worker migrant families and try to understand how it is shaped by this specific pattern of ethnicity, we find that families' work/care strategies are both similar and different to those of the Cape Verdean worker migrant families. As nearly all the families are first-generation labour migrant families, we shall analyse the families as a whole and refer to the few families that do not fall into this migration pattern at the end (there is only one second-generation family and there are two cases of what we might label "lone women's self-assertive" migration pattern; see note 9 , below).

Moroccan families manage work and care for young children through two main types of work/care strategies: mother-centredness and extensive delegation (see table 4). The women who rely on a mother-centred strategy work part-time in the catering, caring or cleaning services, nearly always in private homes where they can negotiate short or irregular working hours which fit in with their children's nursery and primary school timetables. ${ }^{10}$

Safir is a typical example. She is 25 , married and has two children, one aged three and the other seven. As in most couples, her husband immigrated first, in I989, and worked in Turin before settling in Tuscany. He is a waiter in a pizzeria and has a complicated timetable with a morning and a night shift (I I a.m. to 3 p.m., 6 p.m. to I2 midnight, including weekends). He married Safir (his first cousin, living in Morocco) in I993 and she joined him a year later with the eldest daughter. Safir stayed at home for several years caring for the two children. However, now she works in a private home caring for an elderly lady: from 8 a.m. to I 2 midday every morning and two afternoons a week when her eldest daughter has classes until 4 p.m. (state primary school, small fee for canteen service at lunchtime). The younger child stays in the crèche from 8 a.m. to 4 p.m. (no fee, due to the family's low income $\left.{ }^{11}\right)$. Safir is pleased to be working, not only because she earns some money and gets on well with the family she works for but also because she felt very lonely and had difficulties learning Italian during the years she 
Work/care strategies of Moroccan immigrant families (Italy)

Work/care strategy

Number of cases

Managing work and care through mother-centredness:

Mother-centred care

Managing work and care through extensive delegation:

Grandparental care

Extensive formal care

2

Extensive varied care (formal + informal low-cost)

4

Managing work and care through superposition of care upon work:

Formal care (no extras) and workplace

Managing work and care through negotiation within the family:

Shared parental care

Not managing work and care without child negligence:

Formal care (school, no extras) and self-care

stayed at home (she learned by watching TV). The family's main problem now is housing. They have moved several times but their house is small (two rooms) and damp; they have applied for a council house but have been told that this will be difficult to obtain. Safir has a compulsory school educational level and her husband completed secondary school; they have no other family members living in Italy and very few personal friends.

Part-time work thus emerges as a solution that allows women to earn some money without delegating care and household responsibilities extensively. Some women see it as the only possible option for adjusting work and care responsibilities:

"A woman should do these small jobs here, maybe because, how shall I put it, she's forced to do it, what can you do when there are children-you can't abandon your child from 7 in the morning until 7 at night, can you? So the mamma just does little part-time jobs." (Chakiry, 30, eight years in Italy, two children, working part-time)

For those who stayed at home for several years when they arrived in Italy, it is also important to be able to break the social isolation they felt:

"There was nobody to lend me a hand, nobody ringing at the door, nobody, nobody, it really hurt, hurt, I can't tell you. And so now, with the children bigger and the nursery, I go to work." (Sumia, 32, secondary education, six years in Italy, two children aged 5 and 4 ; working in cleaning services since last year; would like to work full-time in a factory)

Combining part-time work and care for young children is not always an easy solution to build up. Many women only manage to find work in the 
mornings and some have to wait a long time before finding such a job. One mother with higher qualifications (secondary school and a diploma in cultural mediation, given by a local training agency) would like to work every morning as her 4-year-old daughter goes to nursery school but she has only found a few hours of work per week. Lastly, in some cases, the part-time work that is available only coincides partially with the normal opening hours of formal care services. In these cases, if the mother wants to work, a mothercentred strategy is no longer possible.

This is Rashida's problem (30 years old, five years in Italy). She does two mornings of cleaning in a private house and she cleans in the evening, from 5.30 to 8.30 p.m., for a cooperative of cleaning services to which she belongs (earning $€$ ir6o per month). Her 3-year-old daughter is in a nursery from 8 a.m. to 4 p.m., so in the evenings Rashida has to take the child to her workplace (superposition of work on care; see table 4). Occasionally, when her husband (a factory furnace worker, working three different shifts that change every week) is on a morning shift (5 a.m. to I p.m.), she will leave the child at home. Rashida would like to have a different job but, in spite of her vocational computer diploma, this is what she has been able to find:

"I would like to find a stable job as a domestic help. But the Italians do not trust foreigners so it is not easy to find... luckily I can take my daughter to work." (Rashida, 30 years old, five years in Italy, a daughter aged 3, married to a factory worker)

She would be ashamed to do this type of work in Morocco but working is important to her - she worked in Morocco as a single woman before migrating and in Italy only stayed at home when she was unable to place her daughter in a public crèche.

Saida (aged 26, six years in Italy, one daughter aged 2) has a similar problem to Rashida. She also has a part-time job with atypical hours working in a restaurant, in the evening from 7.30 to I0.30 p.m. and in the morning during the weekend. However, as her husband has a daytime job (from 7.30 a.m. to 6 p.m., in a furniture factory), Saida has been able to negotiate a shared parental arrangement (see table 4), with the father taking care of the child while she is at work. Saida would prefer to find a job in the morning, when her daughter is at the crèche (to be with other children), but this is the only work she has found and she insists that she does not want to be at home all the time. Saida has vocational training as a secretary and took an Italian language course for immigrants when she arrived.

Extensive delegation, on the contrary, is a strategy that is linked to fulltime work for mothers. Some of the women have fairly standard full-time jobs. For example, cleaning in private homes seven hours per day. But most have long or atypical working schedules in the catering or industrial sectors. In either case, however, due to the rigid and relatively early closing hours of public nurseries and schools in Italy, families usually have to rely on informal low-cost care after nursery or school hours. Only two mothers (see Nadia, above) have access to low-cost nurseries that are open from 8 a.m. until 5.30 p.m., thus enabling them to work full-time and fetch their children after 
work (extensive formal care; see table 4). The others have to rely on extra informal care to supplement formal care services. Grandparental care is a strategy used by first-generation families who managed to bring over a close relative to help with household tasks or care of a baby. Grandmothers (sometimes grandfathers as well) will stay on in an extended family household and take on care responsibilities as well as many domestic tasks.

Amina's family is a typical example. Amina (aged 37) was a low-paid factory worker in Casablanca when she decided to immigrate in the late I980s. She met her husband in I988 in southern Italy and they later moved to the Veneto region. Her mother (aged 6o) carries out most of the household tasks and cares for the I-year-old baby at home as well as her other grandchildren, aged 7 and 8, after school finishes. Amina has a tailoring job in a clothes factory. She works 40 hours a week $(8 \mathrm{a} . \mathrm{m}$. to $\mathrm{I} 2 \mathrm{midday}$ and 2 to 6 p.m.) and earns Єg8o. Her mother has been living with them since I989; in the summer she goes back to Morocco for three months and takes the grandchildren with her.

If grandparental care is not available, it is difficult to obtain other informal unpaid support. Like the Cape Verdean immigrants, Moroccan interviewees say that social networks in the Moroccan community are important but that they do not compensate for the lack of close kin networks which provide help with childcare in the sending country. Although some families get occasional support from Moroccan women who do not work, on a day-to-day basis families feel they have to manage on their own:

\section{"Everybody avoids asking for help to take care of children except in exceptional situations and for short periods of time." (Koudar, 34, nine years in Italy, part-time work from 9 a.m. to 2 p.m. caring for an elderly person, two children aged 7 and 4 )}

Dual-earner couples where both work full-time thus have to make do with other informal resources at hand (extensive varied care; see table 4). For example, in one family there is a paid childminder to look after a 4-year-old between 4 and 8 p.m. (the couple have a shop); in another there is an older (I5-year-old) child who fetches his 9-year-old sister from school (both parents work in a factory). Young children also get sent back to Morocco, for the holidays or for longer periods when they are not yet in primary school.

Considering the difficulties that these dual-earner families have in order to organize work and care for young children, it is not surprising to find some problems of child negligence. ${ }^{12}$ In the Moroccan families it emerges in a couple with a 6-year-old child where both have somewhat atypical working hours. Hadou (32, nine years in Italy, secondary education) does cleaning in a hotel from 8.30 a.m. to 3.30 p.m. during the week and either on Saturday or Sunday mornings, while Said (37, eleven years in Italy, diploma in literature) works alternate shifts in a factory during the week and on Saturday mornings. Their son sometimes stays alone for a few hours after school and on Saturdays and he also stays alone in the holidays when there is no school. This is the situation which worries Hadou most as they have no relatives, friends or neighbours to help provide care during the holidays; she thinks 
there should be more free after-school and holiday clubs to help working couples with young children.

Lastly, it is important to mention that the only second-generation family relies, quite typically, on grandparental support to help provide care for a 4 -year-old child before and after nursery opening hours. Mounia (26, vocational training) is a worker (8 a.m. to 5 p.m., $€_{775}$ ) and her husband works in a bakery (I2 midnight to 8 a.m., €I I,550). Mounia's parents and sisters live nearby so her mother fetches the child in the morning and takes her to nursery school at 9 a.m., a sister fetches her back again at 4 p.m. and leaves her with grandmother until Mounia arrives from work. Mounia would prefer not to work but states that she works to boost family income and to be independent: her husband left her once for months, so it is important for her to know that she can cope on her own. Although Mounia does not wear a veil, she is a practising Muslim and regrets the fact that Muslim workers are not allowed to pray during the stated hours.

Concerning the few lone-parent families in this sample, they do not reveal the pattern of extreme vulnerability we described in some other countries for lone-parent labour migrants. This is mainly due to the fact that they are not typical worker migrants (even if integration and legalization are not always easy for them) and have more resources: some professional qualifications, reasonable income and a few good contacts in the host society (with social services or Italian friends). Malica, a secondary school teacher, came to Italy to get away from a complicated relationship and Sara because she wanted to live with her Moroccan boyfriend. In Morocco, Sara was a bookkeeper in an accountant's office and when she arrived in Italy, she worked illegally in restaurants. When she eventually got her stay permit three years later she worked for a year in a factory with difficult working hours. However, after her child's birth, she managed to get a job in a printing workshop through an Italian friend (8 a.m. to 5.30 p.m., Є730). The couple separated a few months after the birth of the child. Sara was able to find a place for the child in a crèche which is open until 5.30 p.m. all year round (Ego per month); she can also rely occasionally on a sister who is a housewife and lives $30 \mathrm{~km}$ away as well as on a friend who lives nearby.

\section{Factors affecting work/care strategies of Moroccan immigrant families}

In summary, work/care strategies in the Moroccan immigrant families are affected by several factors. Like the worker migrant families in other countries, they have to deal with the absence of close kin, with the long and often atypical working hours of unskilled jobs in the industrial and service sector, as well as with the rather rigid and difficult opening and closing hours of crèches, nurseries and primary schools. Unlike the Cape Verdean families, they also have to take into account the Islamic norms which underline a male breadwinner model. In an effort to adapt to this context and to compromise with the economic demands of migration as well as the norms regarding gender roles, some women look for part-time work and develop mother-centred work/care strategies. Subjectively and objectively this accommodates different demands and constraints and allows women to "leave the house" without seeming 
to leave it for very long. In other families, however, the family's wish to improve its living conditions, women's previous work experiences and the fact that they are living in Italy (i.e. in a migratory context where both members of the couple contribute to the success of the migration project, and far from the sending society where the traditional norms were learned) seem to encourage work/care strategies in which both parents work fulltime and delegate the care of young children to formal and informal carers. Strategies based on extensive delegation are difficult to organize and can often only be set up if formal services, which close early in Italy, are complemented by extra informal solutions such as older child care, a childminder or grandparental support. When these are not available, families may take children to work, send them back to the sending country temporarily or leave them alone at home.

In overall terms, especially when compared to the Cape Verdean families, Moroccan worker families seem to be more vulnerable to problems related to women's isolation and lack of autonomy but less exposed to situations of child negligence. This may be partially explained by the nuclear structure of the Moroccan immigrant family, which usually ensures a male breadwinner and women's part-time work. But it must also be seen in the context of Cape Verdeans' strong social and educational deprivation. For example, Moroccan women have some access to reasonably paid part-time work in private homes as well as more skilled work in factories, whereas Cape Verdean women are more concentrated in full-time cleaning services with atypical hours and very low salaries. Extreme poverty during childhood in the sending or in the host country is also more pronounced in the Cape Verdean families. School dropout and early entry into the labour market make it difficult to avoid negative repercussions for the next generation. Compulsory schooling is accomplished with difficulty and educational mobility, based on secondary school or higher professional or educational qualifications, is hardly considered. This reflects on care and educational strategies, with Moroccan women being openly more conscious of the importance of trying to follow up children's schoolwork (even if they have difficulties with Italian) as well as ensuring the children's participation in different multicultural activities. In short, when we compare first-generation Cape Verdean and Moroccan immigrant families, we find some common patterns of vulnerability. But we also find many specific characteristics, linked to family, educational and cultural differences that make for some specificity within this general pattern of labour migration.

\section{Conclusion}

Patterns of vulnerability and work/care strategies vary greatly according to the migration pattern of the immigrant families. Highly qualified professional migrant families are subject to pressure in terms of long working hours and careers but they seem to be the least vulnerable in terms of childcare. They are usually dual career families that rely on extensive paid delegation which may take the form of care services of the receiving country or facilities provided for foreign children near their workplace (usually private and highcost), sometimes supplemented by paid informal care. 
Unskilled worker migrant families seem to be at the opposite end of the scale. Pressures to work (migration project, low income) and pressures from work - such as atypical or long hours and pressure not to miss work - are the main constraints on family/work life and care strategies for children. Given the income from their jobs, these families must avail themselves of low-cost formal care arrangements with long hours of care, either public or third-sector care facilities or informal care.

Although most labour migrant communities have important social networks which provide support in some situations, interviews show that these informal networks fail to provide support for childcare. This is because time is a rare resource in all labour migrant families and because very close kin, the main provider of childcare in families (Coenen-Huther et al. 1994; Wall et al. 200I), is usually absent or unavailable. As a result, work/care strategies often have to rely on a mixture of individual solutions at hand, such as workplace care, formal care supplemented by older child care or low-cost childminders, and leaving children alone, usually before and after school hours or on Saturdays when parents are working.

Across the four receiving countries and the different countries of origin, the work/care strategies reveal that these difficulties in managing work and care emerge in all the countries where labour migrant families were interviewed. The findings also show that national family policies and the characteristics of the national immigrant groups may vary considerably and lead to a different emphasis being placed on mother-centred care, on formal extensive delegation, on negotiation inside the family or on leaving children alone. This complexity must be remembered and taken into account (see, for example, the contrasts between Moroccan and Cape Verdean families' work/ care strategies). Nevertheless, our main finding is that the overall general trend, in unskilled worker migrant families, is for the latter to be largely excluded from the usual "reconciliation care model" in which normal working hours, formal care services and the family (close kin) offer a balanced interweaving of formal and informal childcare. In fact, this reconciliation care model is strongly cross-cut by patterns of class and racial/ethnic status. Due to lack of close kin, occupational segregation and the characteristics of their jobs, labour migrant families have an unequal access to non-parental childcare. These families belong to working sectors that are insufficiently protected by the welfare state (see Presser i988).

Mixed marriage migration, student migration and asylum-seeker migration present patterns of vulnerability that are less striking in comparison with the labour migrant families. Mixed-marriage migration is related to a specific gender contract in which a foreign wife comes to live and build a family in her husband's country of origin. Mother-centred care prevails and is often linked to problems of isolation as well as difficulties of integration in the labour market when the stay-at-home mother decides to work after raising young children at home for several years.

Student migration of single persons, usually followed by inter-ethnic marriage and permanent settling in the receiving country, is, by contrast, more strongly associated with a family division of paid work based on the dualearner model (both full-time) and a work/life balance emphasizing formal 
extensive delegation of care. Finally, it was observed that asylum-seeker migration in France presents patterns of vulnerability, especially during the first years after arrival, that are often similar to those of worker migrant families. However, asylum seekers receive considerable support in the receiving country in terms of social housing, social benefits and training courses. These measures act as a buffer so that, in comparison with the worker migrant families, these families will more easily achieve a stable work/life pattern in the receiving society. Higher qualifications, where they exist, are also important, as they allow for more resources in establishing contacts and searching for alternatives.

Two final comments are important to summarize some of the issues raised by this exploratory study on immigrant families' work/care strategies. The first relates to the factors affecting immigrant families' work/care strategies. The composition and size of the samples in each country make it impossible to carry out a country-based comparison but they allow us to pinpoint some of the main factors. We have already seen that work/care strategies are strongly influenced by the migration patterns of families. However, within the different types of immigration, some other factors have an impact and introduce some diversification. It is important to mention at least five.

Family structure (couples versus lone parents) is an important variable but only in the more vulnerable types of immigration such as first-generation unskilled worker and asylum-seeker migration: it is here that lone parents with young children are more exposed to social exclusion and to child negligence.

Work and educational trajectories, before and after immigration, also have an impact. For example, many of the more recent worker migrants from Africa have higher educational qualifications (secondary schooling or vocational training) than the former generation of African labour migrants in Europe: this makes for some changes in attitudes to gender roles (and women's work in particular), more flexibility and geographical mobility in the search for jobs and housing and therefore less residential segregation. From the point of view of work/care strategies, this seems to be encouraging work/family patterns more centred on women's full-time work and extensive delegation.

A third factor is related to the patterns of ethnicity. Strong racial and cultural contrasts, especially in the context of illegal and worker migration, seem to reinforce residential as well as occupational segregation. When this strong ethnicity is associated with specific family forms, as in the Cape Verdean immigrant families, difficulties in managing work and care for children increase.

A fourth factor concerns the absence or presence of close kin networks. Findings show that when they exist, either in first-generation families who have managed to bring the grandparents into the host country or in secondgeneration families, grandparental care and support is an important option to help families in their care responsibilities.

Last, the problem of gender. Not surprisingly, since it is at the core of the organization of work/life patterns in families, gender inequality emerged as an important factor in shaping work/care strategies. In one type of immigration, which we labelled mixed-marriage migration, gender inequality is the 
most significant determining factor of work/care strategies: women who migrated through marriage are likely to adopt a male breadwinner pattern and to manage work and care through mother-centredness. Also in the Moroccan immigrant families, a community where culture and religion emphasize women's domestic and caring roles, gender inequality in family roles emerges as an important factor. It encourages some preference for mother-centredness as a work/care strategy but it is not the only influence at work: previous work experiences, negative feelings of isolation at home due to lack of primary networks, as well as the family's migration project to improve housing and living conditions - all these other factors appear to exert pressure in a different direction and to be encouraging work/family patterns based on women's work outside the home.

Finally, it is important to note that gender inequality in the labour market is also an important factor in work/care strategy formation. Labour migrant women working full-time are concentrated in low-paid jobs like the men, but they tend to receive lower salaries. For example, Cape Verdean women in cleaning services earn the national minimum wage whereas the unskilled male workers in the building sector earn well above the minimum wage. Apart from other effects, the main problem from the point of view of work/ care strategies is that labour migrant lone mothers in low-paid jobs have extremely low resources. This makes it difficult for them to buy even low-cost care services and it often leads to work/care strategies based on workplace care, unreliable informal care or leaving children on their own (self-care).

The second comment relates to some policy implications of these findings. First, it is important to underline the need to take into account the diversity of immigrant families. Within this broad category, there are many different worlds: different migration projects and trajectories, diverse family patterns and work/life strategies, variable resources to cope with the difficulties of managing work and care. However, if we focus on the most vulnerable immigrant families - unskilled worker migrant families as well as lone parents within this category - findings seem to point to the still weak regulatory function of the different welfare states in the protection of these families who have low-paid, often atypical, jobs and care responsibilities for young children.

In terms of childcare, it is important to analyse the type of facilities provided by public or publicly subsidized childcare and schools. These are often inflexible, have gaps in their opening hours or close early, even in countries such as France and Finland where formal childcare has been a dominant care arrangement for several decades. Labour migrant families usually need low-cost as well as responsive care services which take into account their income as well as their family-unfriendly working hours. Another policy implication is related to the problem of close kin networks. Although the social networks of economic migrant communities cannot respond to families' childcare needs, a few families are able to bring close kin to help care for young children. Interviews show that this latter solution is not always easy to implement and it will therefore probably depend strongly in the future on family reunification policies that facilitate the entry of close relatives in ascending line.

Finally, another major challenge in terms of social policy lies in gender inequalities in terms of care pressure inside the family and in terms of the 
labour market. Gender inequality in migrant families with low-paid jobs is not easy to tackle. It involves looking at women's training and educational opportunities, their access to the labour market (and to legalized work) when they arrive in the receiving society, the wages and working hours in the employment sectors in which they work as well as the support mechanisms with regard to childcare. Furthermore, attention needs to be focused on policy development with regard to working lone mothers, in particular in countries like Portugal and Italy, where lone parents do not receive extra attention and support.

\section{Notes}

I. Migration patterns may be described and identified on the basis of some of the following dimensions: meanings of/reasons for migration, migration trajectory, migration project, duration of stay or generation (first/second) in the receiving country, position in the social structure of the host society.

2. A longer version of this paper, including an analysis of all five countries, may be found at: http://www.ics.ul.pt/publicacoes/workingpapers/index.htm.

3. The sample also includes a few families where the mother is in training or studying for a $\mathrm{PhD}$.

4. Analysis was carried out on the basis of 63 fully transcribed interviews (including some Finnish interviews translated into English), synopses of all interviews and four national reports (Martin et al. 2002; Trifiletti et al. 2002; Wall et al. 2002; Zechner 2002). For references on immigration, specific migrant communities and social care in each country, see these national reports.

5. Self-care in this paper thus refers to situations where young children aged io or below age io are left on their own for certain periods of time.

6. In Portugal, lone parents have some extra tax reductions but no special allowances. This means that lone parents are expected to work and have a high rate of employment (in 200I, some 73 per cent of lone mothers were in employment).

7. By law all parents in Portugal have to provide maintenance for their children (this is independent of parental responsibility). However, the establishment of maintenance payments will only have to be decided in court if the parents were married and then divorced. In cases of cohabitation or lone parenthood, this only happens if one of them takes the matter to court (a step which, in the families interviewed, was only taken by a highly qualified lone mother, see "Dores" above).

8. There is only one second-generation family: the interviewee was i 3 when she arrived with her mother in the Ig8os to join the father of the family.

9. The two lone parents in the sample are women who separated from their husbands in the receiving country and we may consider them as atypical in terms of their migration and life-course patterns. One lone mother was a middle-class secondary teacher in Morocco; she decided to immigrate in order to avoid a difficult relationship she had initiated and came looking for a fresh start in life. She married a Moroccan travelling salesman, had two children and separated some years later. The other lone mother immigrated to meet up and live with her Moroccan fiancé, without her family knowing. Both these lone mothers were qualified professionals in the sending society and they seem to represent a different kind of migration pattern, more centred on the migration of qualified young women who want to assert their independence and their own way of living. However, as we only have two cases, it is difficult to identify and propose a clearcut migration pattern. 
Io. Nurseries usually close at 4 p.m., and primary schools at lunchtime two days a week and at 4 p.m. on the other days. However, there are also some variations. For example, in the Emilia-Romagna region, some women have access to nurseries that stay open until 5.30 p.m.

II. He earns € 600 and she earns €250. Safir's salary is not declared so social services only take her husband's wage into account.

I2. In the Italian interviews, it was not always possible for the interviewers to check all the gaps in the care arrangements. For example, we do not always know exactly what happens when primary schoolchildren have their two free afternoons or in situations where both members of the couple work on Saturday morning. We therefore think it is likely that the problem of after-school care for young children arises more frequently than would appear from the work/care strategies described in table 4 .

\section{References}

Castles, S. and Miller, M. J. (1998), The Age of Migration-International Population Movements in the Modern World, 2nd edn, London: Macmillan.

Coenen-Huther, J., Kellerhals, J., and von Allmen, M. (I994), Les réseaux de solidarité dans la famille, Lausanne: Réalités Sociales.

Crompton, R. (ed.) (1999), Restructuring Gender Relations and Employment, Oxford: Oxford University Press.

Daly, M. and Lewis, J. (1998), Introduction: conceptualising social care in the context of welfare state restructuring. In J. Lewis (ed.), Gender, Social Care and Welfare State Restructuring in Europe, Aldershot: Ashgate, pp. I-24.

Drew, E., Emerek, R. and Mahon, E. (eds) (r998), Women, Work and Family in Europe, London: Routledge.

Dulk, L. den, Doorne-Huiskes, A. van, and Schippers, J. (eds) (I999), Work-Family Arrangements in Europe, Amsterdam: Thela Thesis.

Garey, A. (I999), Weaving Work and Motherhood, Philadelphia: Temple University Press.

Hantrais, L. (I990), Managing Professional and Family Life: A Comparative Study of British and French Women, Aldershot: Dartmouth.

King, R. (ed.) (1993), Mass Migration in Europe: The Legacy and the Future, London: Belhaven Press.

Mahon, R. (2002), Child care: toward what kind of "Social Europe"? Social Politics, 9, 3: $343^{-79}$.

Martin, C., Debroise, A., and Le Bihan, B. (2002), Care Arrangements in Immigrant Families. National Report: France, SOCGARE Project Report 4.2. Accessed 7 July 2004. Available at: http://www.uta.fi/laitokset/sospol/soccare/reports.htm.

Pires, R. P. (I999), Imigração. In F. Bethencourt and K. Chaudhuri (eds), História da Expansão Portuguesa, vol. 5, Lisbon: Círculo de Leitores, pp. I97-2I I.

Presser, H. B. (I988), Shift work and child care among dual-earner American parents, Journal of Marriage and the Family, 50, 1: 133-48.

Salt, J. (2000), Current Trends in International Migration in Europe, Strasbourg: Council of Europe.

Trifiletti, R., Pratesi, A., and Simoni, S. (2002), Care Arrangements in Immigrant Families. National Report: Italy, SOCCARE Project Report 4.3. Accessed 7 July 2004. Available at: http://www.uta.fi/laitokset/sospol/soccare/reports.htm.

Wall, K., Aboim, S., Cunha, V. and Vasconcelos, P. (200I), Families and support networks in Portugal: the reproduction of inequality, Fournal of European Social Policy, II, 3: 2I3-33.

Wall, K., São José, J. and Correia, S. (2002), Care Arrangements in Immigrant Families. 
National Report: Portugal, SOCGARE Project Report 4.4. Accessed 7 July 2004. Available at: http://www.uta.fi/laitokset/sospol/soccare/reports.htm.

Wall, K. and São José, J. (2003), Immigrant Families, Work and Social Care, SOCCARE Project Report 4. Accessed 7 July 2004. Available at: http://www.uta.fi/laitokset/ sospol/soccare/reports.htm.

Zechner, M. (2002), Care Arrangements in Immigrant Families. National Report: Finland, SOCCARE Project Report 4.I. Accessed 7 July 2004. Available at: http://www.uta.fi/ laitokset/sospol/soccare/reports.htm. 
Copyright of Social Policy \& Administration is the property of Blackwell Publishing Limited and its content may not be copied or emailed to multiple sites or posted to a listserv without the copyright holder's express written permission. However, users may print, download, or email articles for individual use. 